\title{
THE RADIOCARBON DATING AND AUTHENTICATION OF IRON ARTIFACTS
}

\author{
P T Craddock ${ }^{1} \bullet$ M L Wayman ${ }^{2} \bullet$ A J T Jull ${ }^{3}$
}

ABSTRACT. The continuing improvements in accelerator mass spectrometry (AMS) dating technology mean that it is possible to work on ever smaller samples, which in turn, make an ever wider range of sample potentially available for dating. This paper discusses some of the difficulties arising with the interpretation of AMS dates obtained from carbon in iron. The overriding problem is that the carbon, now in chemical combination with the iron, could have come from a variety of sources with very different origins. These are now potentially an iressolvable mixture in the iron. For iron made over the last millennium, there are the additional problems associated with the use of both fossil fuel and biomass fuel in different stages of the iron making, leading to great confusion, especially with authenticity studies.

\section{INTRODUCTION}

The radiocarbon dating of the carbon contained within smelted iron was first proposed and accomplished by Nikolaas van der Merwe (1969). But the radioactive decay was perforce measured by the beta-counting methodology of the day that required approximately $1 \mathrm{~kg}$ of wrought iron to provide the necessary carbon and this precluded its serious practical application. Thus, the ${ }^{14} \mathrm{C}$ dating of iron seemed destined to linger in the limbo of good ideas that are fatally brought down by practical difficulties. The introduction of accelerator mass spectrometry (AMS) ${ }^{14} \mathrm{C}$ dating, capable now of operating on mg-sized carbon samples have transformed the possibilities of obtaining dates from smelted iron (Cresswell 1991, 1992; Harbottle et al. 1993; Kusimba et al. 1994; Cook et al. 2001, 2003). This is an exciting and important extension of ${ }^{14} \mathrm{C}$ dating generally and the recent review by Cook et al. (2003) shows that the dates obtained are very often commensurate with the age estimates made by other methods. However, the very fact that tiny sample weights are now dateable has raised dangers of serious misinterpretation. It is always potentially hazardous to work on samples when one can no longer identify the original form of the material that was the source of the carbon. Sometimes, even when it is apparently possible to identify the material, there are problems because it has been chemically modified, as exemplified below.

The rationale behind the feasibility of the ${ }^{14} \mathrm{C}$ dating of iron is that the carbon in the iron originates from the fuel of the smelting process, and for most ancient iron this fuel will have been charcoal. There seems to be an implicit assumption that the use of fossil fuel can be unambiguously recognized because of the geological age of the carbon (although the possibilities of Neanderthal iron smelting have been raised, apparently seriously, by Sherby and Wadsworth 2001). The potential dangers of serious misdating arising because of the intermixing of carbon from charcoal- and fossil fuel-smelted iron seem not to be appreciated (see Cook et al. 2003, discussed below).

It has been recognized that there is a possibility of contamination where limestone or other carbonate rocks have been used as a flux in the smelting process (Cresswell 1992), or where the iron is extensively corroded (Cook et al. 2003), and Eylon (2002) has documented the reuse of solid wrought iron, that was sometimes centuries old, welded to pieces of much more recent iron. However, it still seems that there has been insufficient attention paid to the potential problems arising from the carbon used in the actual smelting and other processes. This is probably due to a failure to fully realize the complexities of iron-smelting and how much the processes have changed over time. It also seems to be assumed that the histories of the various iron-making processes in use around the world are all known, and that evidence of the production stages to which any iron artifact will have

\footnotetext{
${ }^{1}$ Department of Scientific Research, The British Museum, London WC1B 3DG, United Kingdom.

${ }^{2}$ Department of Chemical and Materials Engineering, University of Alberta, Edmonton T6G 2G6, Canada.

${ }^{3}$ NSF-Arizona AMS Laboratory, The University of Arizona, Tucson, Arizona 85712-1201, USA.
} 
been subjected will be preserved in its structure. In reality, the processes of iron production are both complex and very far from being understood, and very often the later stages of processing the iron will have completely removed the evidence of the earlier stages from the iron of an artifact, while the carbon they introduced remains unaffected but anonymous (Tylecote 1976; Rostoker and Bronson 1990; Craddock 1995:234-83, 1998, 2003).

The problems of the ${ }^{14} \mathrm{C}$ dating of iron were brought home to the authors when trying to get meaningful dates from a lump of iron, found at the village of Churchdown in Gloucestershire, England (Figures 1 and 2). The piece, apparently still containing lumps of its smelting fuel, is described in detail below. To anticipate the discussion of the piece, dates of both 35,000+ BP, and, more specifically, of $2800 \mathrm{BP}$, have led us to finally conclude that the piece is almost certainly of the late 18th to early 19th centuries AD. Clearly the interpretation of the AMS ${ }^{14} \mathrm{C}$ dates obtained on the carbon in iron is not a straightforward exercise!



Figure 1 Half-sectioned lump of iron from Churchdown, Gloucestershire. It is a product of the fining of cast iron to make wrought iron. Note the rectilinear black areas exposed in the section. These turned out to be highly pyrolized hard wood charcoal upon which carbon from the coke-smelted cast iron had deposited. (Photo. British Museum / A. Milton)

This paper will explore some of the problems of interpreting ${ }^{14} \mathrm{C}$ dates obtained from iron, and the confidence with which they can be used. There are 2 rather different scenarios to consider:

1. When the age of the iron artifact is approximately known, stylistically or because the piece is from excavation, and in this case something should be known about the contemporary technology by which the iron is likely to have been produced.

2. When the age of the iron is completely unknown, or where there are 2 or more very different possibilities, such as with an authenticity determination.

In the first case, it is at least possible to predict likely problems arising from the technology, but in the second there will usually exist a bewildering range of possibilities, such that without additional 


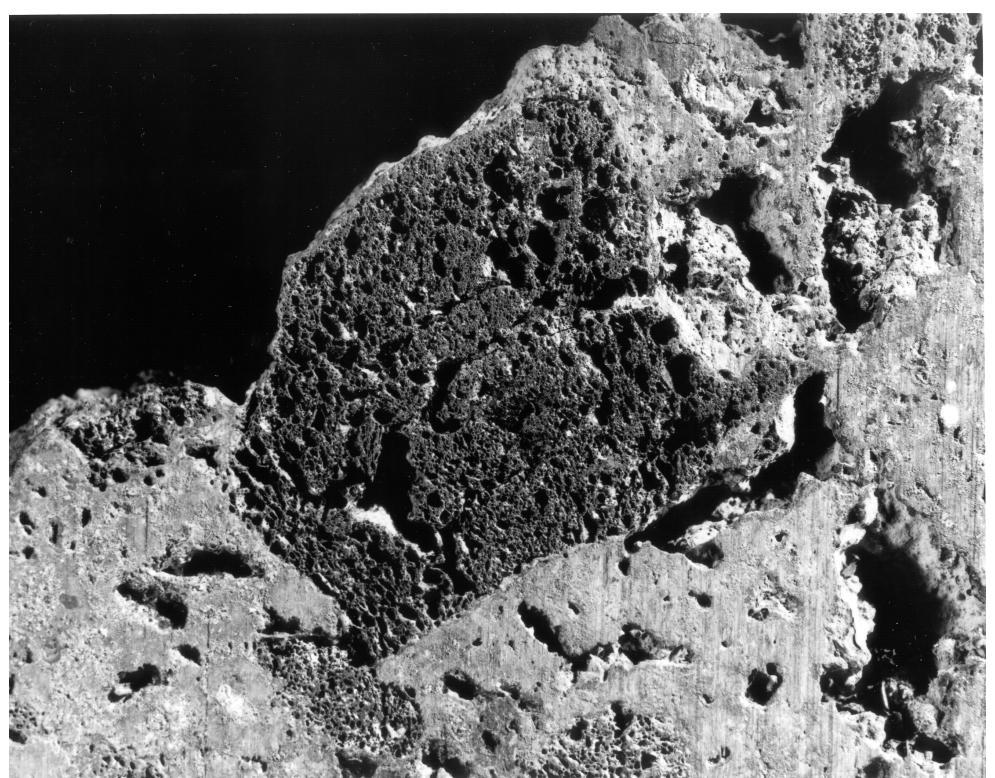

Figure 2 Detail of Figure 1 showing one of the highly pyrolized lumps of charcoal. (Photo. British Museum / A. Milton)

metallurgical or compositional information, any date is possible or explicable no matter what the real age of the object.

First, it is necessary to outline the smelting processes used through the last $3000 \mathrm{yr}$, as far as they are known, concentrating on the potential sources and ultimate disposition of the carbon present in these processes.

\section{IRON AND STEEL PRODUCTION: CARBON IN-CARBON OUT}

The iron ores themselves could well contain significant quantities of carbon in the form of carbonates; siderite, $\mathrm{FeCO}_{3}$, was one of the more common ores used in the past (Pounds 1971), and other ores are often intermixed with limestone. For example, siderite was the main ore used by the Wealden iron industry in southern Britain from the Iron Age to the Industrial Revolution (Cleere and Crossley 1985:11-5). Carbon present in carbonates is expected to be of geological age.

\section{Iron Production by the Direct Process}

Because of its high melting point (about $1550{ }^{\circ} \mathrm{C}$ ), iron was traditionally made by solid state processes often referred to as direct processes. In these, the fuel and reductant was invariably charcoal. In antiquity it is likely that wood of any age would often have been used as a source of the charcoal, and this state of affairs continued until at least the Renaissance in Europe, as illustrated in Biringuccio's Pirotechnia (Smith and Gnudi 1942:177-9), published in 1540, on all aspects of metallurgy and which contains a woodcut illustration showing a woodman about to place a venerable tree bole into the charcoal-making pit (Figure 3). Eylon (2002) has drawn attention to the traditional preference for old oak trees to make charcoal for metallurgical purposes in Lebanon. If these sources of charcoal were used to smelt or carburize iron, then the carbon date could predate the iron by centuries. 


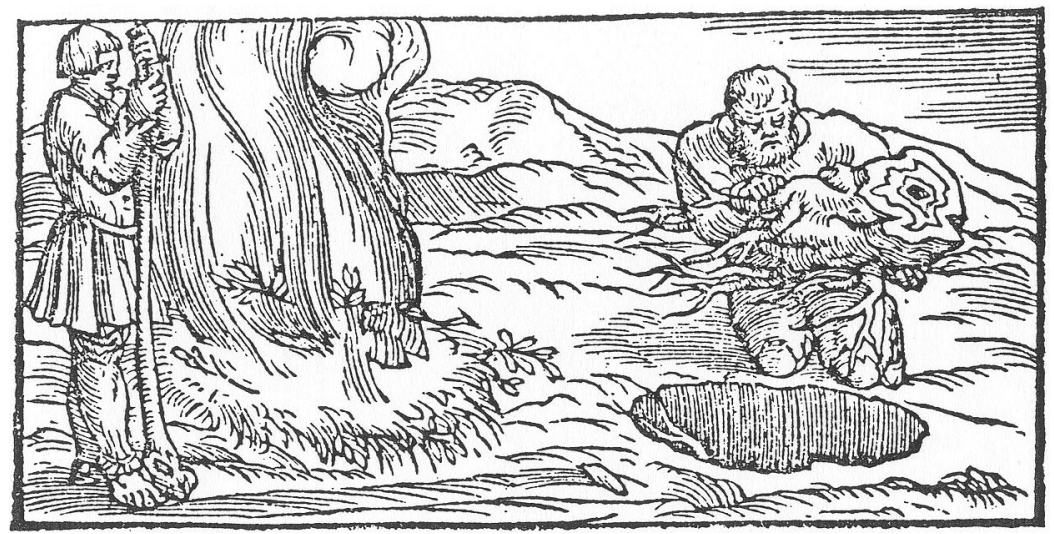

Figure 3 Illustration from Biringuccio's Pirotechnia of 1540, showing an old tree bole being converted into charcoal for use as a metallurgical fuel, the carbon from which could have been laid down centuries earlier.

However, in the post-Medieval period in Europe, and probably much earlier in the Roman period (Fiqueiral in Fulford and Allen 1992) and also in China, production of iron on an industrial scale required a regular supply of charcoal on a large scale. This could only realistically have been met from properly managed woodland producing timber from pollarded trees that were unlikely to have been growing for more than a very few decades when converted to charcoal. In these instances, the carbon date would be close to the date of the metallurgical operations.

It was common practice to roast the ores before smelting, which should have converted most of the carbonates present to oxides (Maréchal 1985; Rostoker and Bronson 1990:52-3). Once the ore was charged into the furnace, further roasting could be expected in the upper or outer reaches of the reaction zone (depending on the furnace type), which were more oxidizing before the ore entered the lower or central region of the furnace where the reduction took place. It seems, however, very likely that some unroasted ore would have dropped straight into the reaction zone where the CO produced by its decomposition could enter the forming iron in the same manner as the $\mathrm{CO}$ from the burning fuel.

In the reaction zone of the furnace, the iron minerals were reduced to tiny platelets of metallic iron protected from reoxidation by the slag. This is where the nascent iron began to coalesce into a solid mass which inevitably contained quantities of the slag in which it had formed. The resulting solid lump of iron, known as the bloom in English, had to be hammered to weld the iron into a more coherent mass and to expel as much of the slag as possible. In order to keep the slag molten, the bloom had to be kept at red heat which required frequent reheating on a hearth. Once an acceptable iron billet had been produced, it could then be forged, that is hammered to shape, an operation once again necessitating that it be frequently returned to the hearth. The hearths were normally fueled with charcoal, but mineral coal, often in conjunction with charcoal, has been found on metalworking hearths, dating from the last $2000 \mathrm{yr}$ at least, all over the Old World in areas where coal abounds from Roman Britain (Webster 1955) to Han China (Wagner 1993).

These processes produced wrought iron with highly variable carbon contents, normally ranging between about $0.01 \%$ and $0.1 \%$ carbon. However, sometimes the carbon content was appreciably higher and there were a very few direct processes in various parts of the world that could regularly produce bloomery iron with a carbon content in region of 0.1 to $1.0 \%$; that is, the iron was produced as a steel. 
Otherwise, steel was produced by carburization of the smelted iron, that is, by prolonged heating of the solid iron billet or artifact in a charcoal hearth, where under intensely reducing conditions some of the $\mathrm{CO}$ gas from the burning charcoal would have been decomposed to deposit elemental carbon on the surface of the iron into which it could dissolve and diffuse. In addition to the charcoal, a variety of other carbonaceous materials, scraps of leather, horn, rags, etc., were recommended by various authorities on iron-making to encase the iron, and all of them were materials that are likely to have been growing very shortly before their use as carburizing agents. The process, sometimes referred to as case hardening if performed on the forged artifact, was slow, laborious, and the results uncertain and heterogeneous.

The obvious solution was to produce iron and steel in liquid forms, and this was achieved at earlier dates and was far more widespread than is presently credited (Craddock 1998, 2003). The implications of this for the viability of ${ }^{14} \mathrm{C}$ dating iron are disturbing.

\section{Iron Production by the Indirect Process}

In the so-called blast furnace, or indirect process, the iron was produced in liquid form known as pig iron or cast iron (irrespective of whether or not it was destined to be a casting). The blast furnace process operated at a higher temperature under markedly more reducing conditions than the bloomery process, such that the forming iron could dissolve the elemental carbon that was deposited on it. Even small quantities of carbon dissolved in iron reduce the melting point by several hundreds of degrees centigrade such that the product was molten iron that could be run from the furnace as pig iron, typically containing between about $3 \%$ and $5 \%$ of carbon. The very reducing conditions meant that separate fluxes had to be added to form the slag and limestone has always been a popular flux mineral. The limestone was not calcined before being charged to the furnace (Tylecote 1976:119).

For the blast furnace process, charcoal was the usual fuel initially, and has remained in use on a limited scale to the present day in countries such as Brazil where timber resources are perceived to be inexhaustible. Fossil fuel in the form of coke or anthracite, seems to have been used in China from the mid-1st millennium AD, developing into a major industry by the beginning of the 2 nd millennium AD (Hartwell 1966, 1967). In the Far East, charcoal-smelting of iron continued on an industrial scale alongside fossil fuel-smelting and is still practiced today to a limited extent, with the obvious potential for confusion when scrap iron made by the 2 processes is mixed. Examination of a selection of Chinese iron castings showed that both charcoal- and coke-smelted iron was being used through the last thousand yr (Craddock et al., forthcoming). In the West, smelting with fossil fuel began in the 18th century and coke was the pre-eminent fuel by the 19th century (Tylecote 1976: 105-20), although, even in Europe and North America (Gordon 1996:90-124) charcoal-smelting continued on a limited scale well into the 20 th century.

Cast iron is a rather intractable material such that the majority of it, in Medieval Europe for example, was converted into wrought iron by burning out the carbon in a process known in English as fining. Usually this was achieved by remelting the iron on a charcoal-fired hearth exposed to the air, and stirring. The iron became progressively more pasty as the carbon content fell and the melting point rose. Some of the iron oxidized and this was removed as a slag by adding fluxes that could themselves contain more limestone, as exemplified by the calcium-rich inclusions in the iron plate found on the Gizeh Pyramid (Craddock and Lang 1993). In the post-Medieval period in Europe, coal was sometimes used on a separate hearth to keep the metal at red heat, but conditions in this hearth were unlikely to have permitted much, if any carbon (or sulphur), to enter the metal. The wrought iron produced by fining is presently indistinguishable from bloomery wrought iron (Rostoker and Dvorak 1990; Starley 1999), and to no small degree this is the reason why the use of the blast furnace 
process over much of Eurasia in the distant past is so little appreciated. This exemplifies the problem prevalent with so much iron production, namely, that the final processes will have removed evidence of the putative earlier stages that potentially could have introduced carbon of geological age.

A variant process used in 18th and 19th century Europe, and possibly also in China at much earlier dates, is known as puddling. Here, the cast iron was melted by heat supplied indirectly by coal and the decarburization was achieved in part by the addition of iron oxide. The puddling was carried out in a reverbatory furnace where there was no direct contact between the coal and the metal. The gases burning over the metal would have been carbon monoxide from the coal, but this should not have entered the iron in any quantity as the whole point of the operation was to burn out the carbon the iron already contained, rather than introduce more.

The production of cast iron began in China early in the 1st millennium BC, and was probably used initially just for castings, but soon became the usual method of producing iron whether for castings, for fining to wrought iron, or for partial decarburization to steel (Wagner 1993).

In Europe, this sequence of developments seems to have been reversed, with all the early cast iron being turned into wrought iron. There is now archaeological evidence of iron-smelting sites where the blast furnace process was developing from the beginning of the 2nd millennium AD. These smelting sites have calcium-rich slags, and are always associated with fining hearths, and predate the first iron castings in Europe by several centuries (Magnusson 1985; Gassman et al. 1995; Knau and Sonnecken 1994). Note, the evidence is all from the smelting sites, there is presently no way of recognizing the fined iron produced by these furnaces in the surviving iron artifacts.

The situation in central and southern Asia and in the Middle East is not clear. Contemporary documentary evidence would seem to suggest that the blast furnace process may have been widely used throughout Islamic lands (Allan 1979:72-5) and India (Craddock 1998), but as yet there is no artifactual or archaeological evidence.

\section{Steel}

Steel could be produced from cast iron by controlled de-carburization, stopping just short of the total removal of the carbon, although this was only practiced to a minor extent. The usual practice was to start with wrought iron and subject it to a carburization process. In addition to the case hardening processes mentioned above, a number of other processes developed.

One method of exposing the wrought iron to carbon that it could easily absorb was to soak solid wrought iron in liquid cast iron, so that some of the carbon transferred to the wrought iron converting it to steel. The best description of this process is given by Biringuccio (Smith and Gnudi 1942: 67-70). It was practiced in Renaissance Italy, where it was known as the Brescian process, but it seems likely that the process was fairly widely used across Eurasia. In Biringuccio's description, the bath of molten cast iron, which would have been smelted with charcoal, was protected from oxidation by a slag formed from marble chips. This would have decomposed releasing the carbon from the geological-age carbonates, some of which could have dissolved into the cast iron. As with many other processes, the Brescian process is known mainly from a very few contemporary descriptions, the history and extent of the technology is completely unknown.

In post-Medieval Europe the cementation process was developed for the production of steel. Here, bars of wrought iron were packed into large stone chests with charcoal and heated for periods of up to several weeks before being removed and forged to bars, often referred to as shear and double shear steel (Barraclough 1984a). By the 19th century, there is the possibility that some of the wrought iron 
bars could have been smelted with coke, and after the cementation process with charcoal, the residual coke-derived carbon from the original iron-smelting process together with the charcoal-derived carbon could combine to make the iron appear some centuries older than it actually was.

Bulk steel production began with the Bessemer process in the 1850s, followed by the open hearth process in the 1880s (Barraclough 1990:39-56, 137-63). Both of these made steel by burning the carbon out of pig iron at very high temperatures. Usually the pig iron was freshly made metal, smelted with coke. Such fuel as was used in the open hearth process was coke and, thus, all the carbon was of geological age, and this could not be confused with charcoal-smelted iron. However, this was bulk steel, and a fair amount of the charge was often made up of scrap, which could of course include charcoal-smelted iron, Sweden, for example, was still a major producer of charcoal-smelted iron well into the 20th century. The remnant carbon from such a mixture could give a wide range of carbon dates.

\section{Crucible Steel}

Steel could also be produced as a liquid, and this technology has a long history, the extent of which is only now being fully realized (Bronson 1986; Craddock 1998, 2003; Allan and Gilmour 2000).

In Asia, 2 very different crucible processes for the production of liquid steel evolved from the latter part of the 1st millennium BC (Craddock 1998, 2003; Lang et al. 1998). In 1 process, wrought iron and carbonaceous materials were strongly heated in small crucibles, causing some of the carbon to enter the iron, forming a steel typically with about 1 or 2 percent of carbon. The carbonaceous material came from a variety of wood and other plant sources that are unlikely to have been of any great age at the time of their use in the crucible steel process. Alternatively, a mixture of wrought iron and cast iron could be melted together in the crucibles to give a steel once again typically containing between 1 and 2 percent of carbon. Little is known of the production of cast iron for the crucible steel process; if Chinese cast iron were used, then clearly it could contain carbon from fossil fuel. The Indian crucibles were regularly heavily tempered with straw, probably coming chiefly from the use of dung as a temper, and it is suggested that some of the carbon from these tempers could have entered the iron.

By the early Medieval period, crucible steel was in common use throughout the Middle East and South Asia as the usual quality steel for a wide range of tasks, well beyond the more familiar Damascus-patterned blades, as the recent study of Allan and Gilmour (2000) has demonstrated.

In Europe, a very different approach to the crucible steel process was developed utilizing cementation steel. This was melted to homogenize it and to remove the slag. The process was introduced by Benjamin Huntsman in Sheffield in the 1740s and by the early 19th century it was the usual method of producing crucible steel in Europe and North America. A recent report suggests that liquid steel was being produced in Saxon England almost a thousand yr earlier, although nothing is presently known about the process that could have produced it (Mack et al. 2000). This does, however, serve to illustrate how incomplete our knowledge is of the various ironmaking processes.

Latterly, the Huntsman process was largely supplanted in Europe and in North America by other crucible processes. The co-fusion process was quite widely used in the 2 nd half of the 19th century, and in-situ carburization of the iron in the crucible with charcoal became general by the end of the 19th century (Carnegie 1913:51; Craddock and Wayman 2000).

Although the carbon in the cementation iron was derived from charcoal, and the reductants, where used, were also of charcoal, it was common practice to add either graphite, or latterly coke dust to 
the clay from which the crucibles were made, and this increased the carbon content of the steel (Barraclough 1984b: Table 1, p 54; Freestone and Tite 1986). Also, from the end of the 19th century at the latest, the wrought iron feedstock in all of these crucible processes would normally have been coke smelted.

Thus, overall, there are strong possibilities of intermixing carbon from recent and ancient sources, especially from charcoal and fossil fuel, and where charcoal- and fossil fuel-smelted cast iron exist together to be mixed as scrap. The problems created by multi-stage processes using carbon from different sources are well-exemplified by the following case history.

\section{THE CHURCHDOWN LUMP}

The lump of iron shown in Figure 1 was found buried in the surface of pasture land in the village of Churchdown in Gloucestershire, where it had clearly lain for some time. There were no other indications of iron production in the immediate vicinity, although Churchdown lies only a few km from the traditional iron-smelting area of the Forest of Dean, from where the lump very possibly came. From its shape and the vitreous material on the surface, the iron had clearly been very hot, and the finder, Mr Michael Hynd, initially wondered if it could be a sideritic meteorite, and cut a large slice from the center of the lump. This revealed the presence of numerous subrectangular areas, which although very ferruginous, were also very dark and had an open, somewhat pyrolized structure. $\mathrm{Mr}$ Hynd took his find to the Natural History Museum in London, where they were able inform him straight away that it was not a meteorite but could be an iron bloom, and suggested that he take it to the British Museum.

On first seeing the sectioned lump, the rather pyrolized structure of the black areas suggested that they were coke. If this was the case, then the iron could either have been a lump of cast iron, which had been coke-melted in a cupola furnace at some foundry and would have been of little interes,t or it could be a piece of cast iron in the process of being fined with coke, an unusual but not impossible scenario, and a rare if not unique survival of an intermediate stage of wrought iron production from the time of the Industrial Revolution. The other method of converting cast iron to wrought iron, puddling, was unlikely as that process used coal out of contact with the iron and the forming wrought iron has a distinctive slag content that was entirely absent here. However, expert examination by Caroline Cartwright, of the Department of Scientific Research, British Museum, showed that the black pieces had in fact once been charcoal, now heavily pyrolized and infiltrated with iron, such that it was impossible to determine the species of wood, beyond that it was likely to have been a hard wood (Figure 2). Also, at this stage, preliminary metallographic examination showed that the iron was predominantly of ferrite with a little heterogeneously distributed pearlite, that is a wrought iron. Given the size, shape, unconsolidated appearance, and the inclusions of charcoal, it now seemed very likely that this was a bloom of iron straight from the direct process furnace. This would also be a very rare survival indeed, and one that the Museum would wish to acquire and study (It is hoped that the metallographic report on this piece be published in the Journal of the Historical Metallurgy Society). This immediately raised another more practical problem, the lump was without any immediate context but found near to the Forest of Dean where iron had been smelted from the Iron Age to the 20th century (Hart 1971:1-209), and, thus, we had no idea at all of the date. We did not even know which was the appropriate Department in the British Museum to access it!

Thus, a selection of the iron-rich black pieces was sent to Arizona for AMS ${ }^{14} \mathrm{C}$ dating. The sample was pretreated in $1 \mathrm{~N} \mathrm{HCl}$ for several days and a considerable amount of $\mathrm{Fe}$ was dissolved. The remaining material was combusted at $900{ }^{\circ} \mathrm{C}$ with $\mathrm{CuO}$. Two separate combustions were made. The 
sample $\mathrm{CO}_{2}$ was then reduced to graphite over iron powder and the graphite was pressed into an AMS target. The sample target was mounted in a sample wheel with other samples and 8 standards (oxalic acid I and II, NIST SRM-4990B and 4990C). The measurements were made as described by Donahue et al. (1990a, 1990b).

The results were:

$$
\begin{array}{ll}
\text { AA }-42636 \mathrm{~A} 16.0 \% \mathrm{C} & 35,940 \forall 760 \\
\text { AA }-42636 \mathrm{~B} 9.4 \% \mathrm{C} & 36,230 \forall 800
\end{array}
$$

This showed that fossil fuel had been used, seemingly suggesting that the black pieces were coke as originally thought. Caroline Cartwright once again examined the pieces and was adamant that, although severely modified, the pieces were, or had been, charcoal. This time she actually took a small sample of the material that she believed was charcoal, and that was not in contact with the iron (this was not as easy as it might seem, as the iron and carbonaceous material are in very intimate contact). This sample (4.5 mg) was sent to Arizona and pretreated with the standard acid-alkali acid pretreatment. The result was as follows:

$$
\text { AA }-44357 \quad 66.5 \% \mathrm{C} 2,798 \forall 43
$$

The high $\mathrm{C}$ content of this sample clearly indicates that it is charcoal. Since this represents the age of the wood, it is clearly a better estimate of the time of firing of the iron than the earlier date.

In the meantime, further metallography done on the lump itself showed that the iron had significant quantities of iron sulphide inclusions, which together with the geological age of the first sample, strongly suggested that the iron had indeed been smelted with fossil fuel.

The possibilities were either to take the dates at face value and argue that this was coke-smelted iron which was being fined with charcoal made from ancient bog timber, or to seek other explanations. The first option is extremely unlikely, there is no record of the use of bog timber for making charcoal or indeed for its use in industrial processes generally, and there is no known source of such material within the Forest of Dean area.

It is more likely that the intense reducing conditions within the burning charcoal can provide the explanation. The overall purpose of the fining was to burn the carbon out of the putative cokesmelted cast iron as gaseous $\mathrm{CO}$ and $\mathrm{CO}_{2}$. The function of the charcoal was to provide the heat to melt the iron and energy necessary. Thus, the original AMS ${ }^{14} \mathrm{C}$ date showed that the small amount of carbon left within the iron was the original carbon from the smelting process. This was to be expected as the whole purpose of the fining process was to create conditions where carbon left the iron, not entered it. However, where the gases had permeated into the intensely reducing conditions inside the burning charcoal, some of the $\mathrm{CO}_{2}$ and $\mathrm{CO}$ had been reduced back to elemental carbon and deposited on the charcoal. Thus, the charcoal, produced from timber that had very likely been growing recently, was coated with carbon of geological age, coming ultimately from the coke used in smelting. This process could also explain the anomalous early date of the charcoal lump in one of the Frobisher blooms (see below).

If in the first instance, the carefully selected 2nd sample of charcoal had been sent to Arizona, there is a possibility that the Churchdown ingot could now be hailed as an important survival of early Iron Age iron production technology in Britain. As it is the combination of the AMS ${ }^{14} \mathrm{C}$ date of geological age from the iron itself, the much younger date from the charcoal and the numerous sulphide 
inclusions allows us to identify the lump as belonging to the charcoal-fining of coke-smelted iron (NB as described below the distinctive sulphur contents are only found in early coke-smelted irons).

As explained above, the use of coke to smelt iron only became general in Britain after the mid-18th century and the charcoal-fining process was finally superseded by the puddling process by the early 19th century. Thus, the AMS ${ }^{14} \mathrm{C}$ dates of geological age for the carbon in the iron and $2800 \mathrm{BP}$ for the charcoal really do allow us to confidently assign this piece to between the late 18th and early 19th century.

\section{DISCUSSION}

There are clearly a number of potential contributions to the smelted iron from carbon other than that contained in the charcoal of the smelting process, which may itself have been made from wood of some age. It is proposed to review these in technological sequence, discussing some of the inherent problems in recognizing the presence of old carbon, from whatever source.

1. At every stage there is the possibility of carbonates associated with the ore surviving a putative roasting process.

2. The blast furnace process regularly used limestone as a flux. Cresswell (1992) has already noted that the presence of calcium in the slag inclusions in the iron is a danger signal that the carbon may be contaminated with carbon from the flux. However, blast furnace iron should retain few, if any, slag inclusions from the primary smelting, and if the iron has been fined to wrought iron then it will be impossible to establish even that it had been blast furnace iron, let alone whether or not it was fluxed with limestone. The inclusions that are present will be associated with the secondary fining process, but the majority of the remaining carbon will be from the original smelting, by whatever process. Given that the history of the blast furnace process commences very early in China, and that it is of very uncertain, but potentially early use in the rest of Eurasia, this puts the ${ }^{14} \mathrm{C}$ dating of wrought and cast iron on a very uncertain basis for most places at most times through the last $1000 \mathrm{yr}$ or so. Any piece of wrought iron from a large part of the Old World over the last $1000 \mathrm{yr}$ or so potentially may have been made by fining cast iron smelted with a limestone flux, or it might not—we presently have no way of telling from the iron itself.

3. In the fining of the iron, limestone was sometimes added as a flux, and coal was used on a minor scale in the hearths.

4. Old wrought iron was sometimes re-used by welding it together with other pieces of recycled or newly smelted iron.

5. Once iron was being melted, then part of the feedstock could be scrap iron. The danger here is two-fold. There is a danger of old charcoal-smelted iron forming part of the feedstock along with more recent charcoal-smelted iron. However, the problem becomes much worse if charcoal- and coke-smelted scrap is mixed. Where such mixed scrap is used, then the carbon from the resulting wrought or cast iron could give any ${ }^{14} \mathrm{C}$ date across the entire range covered by ${ }^{14} \mathrm{C}$ dating, and there is no warning or way of ascertaining that such admixtures are present in the iron. Qui Shihua and Cai Lianzhen (1986, quoted in Wagner 2001:52-3), turned the question round and used AMS ${ }^{14} \mathrm{C}$ dates of between $11500 \mathrm{BP}$ and $13800 \mathrm{BP}$ obtained from 3 artifacts of cast iron belonging stylistically to the Song and Yuan periods in China, and thus in reality rather under $1000 \mathrm{yr}$ old, to calculate the relative proportions of charcoal- and fossil fuelderived carbon that was likely to be present in these castings. They assumed that the carbon all derived from a single operation and from the figures that they had obtained, calculated the proportions of charcoal and coke that were likely to have been present in the original smelting 
charge. Given the other imponderables such as the possible of use of limestone fluxes etc., the precise figures quoted of a furnace charge of $30 \%$ charcoal and $70 \%$ coal seem a little optimistic. In fact, the use of a mixed charcoal-fossil fuel mixture is otherwise unknown. The more likely scenario is that the mixture arose from melting together charcoal- and coke-smelted scrap iron. It must be of concern that there is no way of determining the real explanation.

6. Recognition of the presence of fossil fuel in the iron. It might seem that it would be relatively easy to spot iron that has been smelted with fossil fuel, even if the carbon date was equivocal, because of the high sulphur content, as was the case with the Churchdown lump, described above, for example. The first Chinese irons smelted with fossil fuel do indeed have recognizably higher sulphur contents than those smelted with charcoal (Han Rubin 1996; Craddock et al. in press), as does the first coke-smelted iron from England, which has given the impression that all iron smelted with fossil fuel has elevated sulphur contents. This is simply not so, as even trace levels of sulphur result in serious embrittlement during hot working of the metal, every effort was and is made to keep the sulphur content in iron to a minimum. The much higher temperatures achieved in the iron-making processes from the mid-19th century effectively reduced the sulphur content in the pig iron down to levels similar to those found in earlier charcoalsmelted iron.

7. The problems of establishing the origin of the carbon in steels are basically similar to those for iron generally. With crucible steels there is the special problem of the widespread use of graphite or coke as a constituent of the crucibles that held the molten charcoal-smelted cementation steel.

As noted in the "Introduction", the material for dating is likely to fall into 1 of 2 categories, those pieces where there is some chronological or typological indication of the likely age of the piece, and those where there is none.

\section{DATING MATERIAL FROM EXCAVATED, OR AT LEAST KNOWN, CONTEXTS}

Even where there is some indication of period, and so that the processes behind the iron should be understood, there can still be problems of interpretation. The Frobisher blooms provide an interesting example.

The story behind the voyages of Martin Frobisher, who in the 1570s initially went in search of the North West passage around North America, before becoming side-tracked into an equally fruitless search for gold, is long and complex and has been told many times (McFee 1928; Kenyon 1975; Fitzhugh and Olin, editors 1993). Not least of the conundrums left by the expedition are the famous Frobisher blooms. A 19th century expedition to Frobisher's base on Kodlunarn Island in Frobisher Bay off Baffin Island came back with several iron blooms, one of which was subsequently ${ }^{14} \mathrm{C}$ dated by Sayre et al. (1982) by gas counting using miniature counters. This gave a date of $679 \forall 133 \mathrm{BP}$,

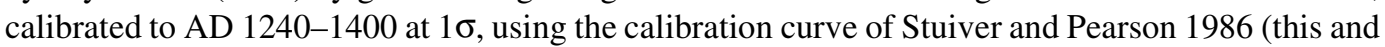
the following dates are taken from Harbottle et al. 1993:Table 10.1). The date is apparently much too old for the iron to be associated with the Frobisher expedition. The 1981 Smithsonian Expedition to Kodlunarn Island found 3 more blooms in association with a smithy. Two of the recently discovered blooms have been AMS ${ }^{14} \mathrm{C}$ dated (Harbottle et al. 1993). Once again, they gave dates that were apparently too old to have been associated with the Frobisher expedition. Suggestions had been put forward many years ago that the blooms discovered in the 19th century could have been made by the Vikings who were in the area centuries before Frobisher. However, the discovery of mineral coal at the smithy in association with the blooms raised other possibilities, and further complicated the matter. The main dating interest centers on Bloom 2, which was sectioned and samples taken from sev- 
eral locations. In 1991, Cresswell reported a date of $1340 \forall 70 \mathrm{BP}$, (calibrated to $640-760 \mathrm{AD}$ at $1 \sigma$ ) for a sample taken from the outside of Bloom 2, and a date of $920 \forall 60$ (calibrated to 1006-1150 AD at $1 \sigma$ ) for a small inclusion of charcoal found beneath when the section was cut. At this stage, although admitting the possibility of an earlier Viking origin, Cresswell seemed to have supported the explanation of Elizabethan smelting using a mixture of charcoal and mineral coal, but stated that additional dates from deeper within the bloom were necessary to resolve the problem. In 1992, Cresswell duly reported on 2 more dates on Bloom 2, 1 taken about $2 \mathrm{~cm}$ into the metal, which gave a date of $550 \forall 60 \mathrm{BP}$ (calibrated to $\mathrm{AD} 1307-1355$ at $1 \sigma$ ), and one of $500 \forall 60 \mathrm{BP}$ (calibrated to AD 1400-1442 at $1 \sigma$ ), from about $5 \mathrm{~cm}$ depth (which was about the center of the sectioned bloom at that point). Cresswell noted the obvious, the further in the younger the age, but added, "These dates are closer to Elizabethan in origin, and suggest multiple sources of carbon used for the smelting." Thus, he still seemed to have believed the blooms to be Elizabethan. Yet, $1 \mathrm{yr}$ on Harbottle et al. (1993) (with Cresswell as one of the authors) concluded on the basis of the same carbon dates that the blooms were after all likely to be Viking. A separate metallographic examination of all the metallurgical debris on the site including the blooms had concluded that although there was possible evidence of attempted smelting, the blooms were likely to have been earlier (Unglik 1993). Citing supporting documentary evidence (see below), both Harbottle et al. (1993) and Wayman and Ehrenreich (1993:213, fn) suggested that the Frobisher expedition had picked up the blooms locally, and had heated Bloom 2 strongly with coal, which had carburized the surface with geological age carbon.

The evidence supporting this interpretation is quite strong. It would seem to make no sense at all for the expedition to bring out half-formed iron as blooms from England when space on board the ships must have been at a premium (although there is an inventory of the materials carried by the expedition which lists "osmondes" of iron, and the word osmonde was sometimes used in Tudor England to denote ingots of iron) (Fitzhugh and Olin 1993:24). There is, however, another significant reference in the journal of Edward Fenton, captain of one of the expedition's ships on the third Frobisher expedition, that they had found "divers osmondes of iron", in the vicinity of Kodlunarn Island (Harbottle et al. 1993:174). These could be osmondes brought out on the previous expeditions, or the Frobisher expedition could have stumbled across an old Viking iron-making site, where unsuccessful blooms had been abandoned, which was common practice. So it could be that the expedition collected and tried to work them using some of the considerable quantity of mineral coal and charcoal brought out for the projected gold mining and working operations. Laeyendecker (1993) raised yet another possibility, namely that the expedition had smelted the iron locally, using old driftwood as a source of the charcoal.

However, our concern here is not primarily with the real origin of the Frobisher blooms, but merely to comment on the disparity of the dates. Bloom 2 has 4 dates spanning almost $1000 \mathrm{yr}$ in the space of about $10 \mathrm{~cm}$. If one takes the dates of the 2 inner samples as representing the age of the charcoal that was used for the near contemporary smelting of the iron, then there are still problems. The dates of the 14th and 15th centuries are rather too young for the Viking settlements that had shrunk away to almost nothing by this time, but conversely are still too old for the Elizabethans, unless some allowance is made for the possibility of some old carbon in the ore/flux, and for old wood being used for the charcoal or for coal being used on the hearth. Another problem is the discrepancy in the date of the charcoal inclusion in Bloom 2 and the dates of the 2 interior samples. The charcoal inclusion is apparently several centuries older than the carbon of the iron which it smelted. A possible explanation is that the later putative heat treatment with coal as well as carburizing the surface of the bloom also deposited some geological-age carbon on the charcoal, with a mechanism somewhat 
similar to that postulated for the charcoal in the Churchdown lump, described above, only with the carbon coming from the fuel rather than the iron.

Overall, the small counter and AMS ${ }^{14} \mathrm{C}$ dating of the Frobisher blooms has produced a lot of seemingly contradictory data, sometimes on the same bloom, without producing a firm "right" date or even consensus on the origin of the iron. It does exemplify again the problems of AMS ${ }^{14} \mathrm{C}$ dating of iron, especially where the possibility exists of both fossil fuel and charcoal being involved, together or at different stages in the operation.

\section{DATING OF IRON WHICH HAS NO CONTEXT}

In the 2003 paper by Cook et al. on the AMS ${ }^{14} \mathrm{C}$ dating of rusty iron, the opportunity was taken to publish the AMS ${ }^{14} \mathrm{C}$ dates obtained on some (unrusty) samples taken from 6 pieces of body armor that purport to be German or Italian of the 15th to 17th centuries AD, and are now in the collections of the Metropolitan Museum of Art, New York. Only 1 of the 6 dates was in broad agreement with the art historical dates, the other 5 had AMS ${ }^{14} \mathrm{C}$ dates varying from $570 \mathrm{BP}$ back to $4250 \mathrm{BP}$. The authors suggest that some carbon could have come from the ore/ flux, the use of old charcoal (Figure 2), and the possible use of coal in the smithing hearths, which would all have tended to increase the apparent age and thereby explain some of the discrepancies. However, most of the discrepancies are very large, indicating to Cook et al. that a considerable percentage of the carbon in the iron must be of geological age. The explanation offered was that the iron was smelted with a mixture of charcoal and coal, and that the previously held view, that smelting iron with fossil fuel began later in Europe, would have to be revised.

There is, of course, a much more plausible explanation to accommodate the use of fossil fuel in the production of the iron that does not necessitate rewriting the history of metallurgy, namely that the armors are not of the age suggested by their typology, but are, in fact, 19th century copies. The carbon content of the iron could then be explained as either coming from the mixing of charcoal- and coke- smelted scrap iron, or by the carburizing of coke-smelted iron with charcoal.

There are a number of disturbing factors here. It is especially worrying that, no matter what the real date of the iron, the AMS ${ }^{14} \mathrm{C}$ dates show the general frequency of the admixture of carbon derived from both fossil fuel and charcoal in the iron. It is also disturbing that though the range of proffered AMS ${ }^{14} \mathrm{C}$ dates is very wide (from 230 to $4850 \mathrm{BP}$ ), with one exception they still manage to lie outside the almost equally wide range of realistic dates, which lie from 50 to $500 \mathrm{BP}$.

\section{CONCLUSIONS}

Overall, there is a strong possibility that iron submitted for ${ }^{14} \mathrm{C}$ dating will have been subjected to several processes involving heat, reduction, oxidation and carburization with a variety of fuels and fluxes containing carbon in a variety of forms, and this is likely to cause problems in the interpretation of the ${ }^{14} \mathrm{C}$ date.

In the examples quoted above of some Viking(?) blooms, "Medieval" armor, and the Industrial Revolution lump from Churchdown, one could have predicted that the carbon would have been from charcoal in the first 2 cases and coke in the 3rd. In reality, all turned out to be mixtures of unknown and unknowable proportions, fatally compromising the possibility of obtaining real dates by ${ }^{14} \mathrm{C}$ dating alone. That having been said, it must be stated that in each case the radiocarbon determinations did provide valuable information which, used in conjunction with other information, helped to elucidate the possible histories of the irons concerned, even if it could not provide a direct date as such. 
However, the detailed and quite destructive sampling of the Frobisher bloom and the Churchdown lump, which was necessary, is clearly not possible on the majority of artifacts.

For authenticity investigations, an AMS ${ }^{14} \mathrm{C}$ date of many hundreds or thousands of $\mathrm{yr}$ for an iron artifact could be the result of charcoal-smelting at that time, or the fortuitous (or even possibly deliberate) mix of charcoal- and coke-smelted irons.

Where there is no independent indication of age, there are major and probably insurmountable difficulties in producing not just a reliable date, but even convincing evidence of age. This is due in the main to the possibility of unquantifiable intermixes of carbon of geological and recent age in the iron smelted or cast in the last couple of centuries being mistaken for charcoal-smelted iron of much greater age. For many classes of artifact, knowing that this possibility existed, it would be possible to offer a series of equally plausible explanations for almost any date from the recent past to the Upper Paleolithic.

For many periods and places, we simply do not know the basic technology by which the iron was produced. Even more worrying, in most instances the last process such as fining or crucible melting will have removed all tangible evidence of the earlier processes having taken place. Without the evidence of the original form of the carbon the various possible interpretations of the AMS ${ }^{14} \mathrm{C}$ dates obtained would be impossible either to refute or confirm.

\section{ACKNOWLEDGEMENTS}

We are grateful to Mr Michael Hynd for presenting half of the Churchdown lump to the British Museum. But for his initial interest in the object that had damaged the blades of his motor mower as he drove over it, a rare but an important survival of Industrial Revolution iron-fining practice would have lain unrecognized. We are also grateful to Caroline Cartwright for her examination of the black material in the Churchdown lump and for insisting on their being of charcoal, when all around were assuming on the basis of the AMS dates that they must be coke, and to Janet Ambers and Sheridan Bowman for reading drafts of the paper and making helpful comments. We are also grateful to Andrea Cook for giving us access to her published and unpublished work and for positive discussions with her on the origins of the carbon in iron, although our interpretation of the data was not always the same.

\section{REFERENCES}

Allan J. 1979. Persian metal technology. London: Ithaca Press.

Allan J, Gilmour B. 2000. Persian steel. Oxford: Oxford University Press.

Barraclough KC. 1984a. Steelmaking before Bessemer 1. Blister Steel. London: The Metals Society.

Barraclough KC. 1984b. Steelmaking before Bessemer 2. Crucible Steel. London: The Metals Society.

Barraclough KC. 1990. Steelmaking: 1850-1900. London: The Metals Society.

Bronson B. 1986. The making and selling of Wootz: a crucible steel of India. Archeomaterials 1(1)13-51.

Carnegie D. 1913. Liquid steel: its manufacture and cost. London: Longmans Green.

Cleere H, Crossley D. 1985. The iron industry of the Weald. Leicester: Leicester University Press.

Cook AC, Wadsworth J, Southon JR. 2001. AMS radio-

carbon dating of ancient iron artifacts: a new carbon extraction method in use at LLNL. In: Carmi I and Boaretto E, editors. Proceedings of the 17th International ${ }^{14} \mathrm{C}$ Conference. Radiocarbon 43(2A):221-227.

Cook AC, Wadsworth J, Southon JR, van der Merwe NJ. 2003. AMS radiocarbon dating of rusty iron. Journal of Archaeological Science 30(1):95-102.

Craddock PT. 1995. Early metal mining and production. Edinburgh: Edinburgh University Press.

Craddock PT. 1998. New light on the production of crucible steel in Asia. Bulletin of the Metals Museum of the Japan Institute of Metals 29:41-66.

Craddock PT. 2003. Cast iron, fined iron, crucible steel: liquid iron in the ancient world. In: Craddock PT, Lang $\mathrm{J}$, editors. Mining and Metal Production Through the Ages. London: BMP. p 223-48.

Craddock PT, Lang J. 1993. Gizeh iron revisited. Journal 
of the Historical Metallurgy Society 27(2)57-9.

Craddock PT, Wayman ML. 2000. The development of European ferrous metallurgy. In: Wayman ML, editor. The Ferrous Metallurgy of Early Clocks and Watches, X. London: British Museum Occasional Paper 136. p 13-29.

Craddock PT, Wayman ML, Wang H, Michaelson C. Chinese cast iron through 2500 Years. In: Jett P, editor. Scientific Research in the Field of Asian Art. London: Archtype Books. Forthcoming.

Creswell RG. 1991. The radiocarbon dating of iron artefacts using accelerator mass spectrometry. Journal of the Historical Metallurgy Society 25(2):76-85.

Cresswell RG. 1992. Radiocarbon dating of iron artefacts. In: Long A, Kra RS. Proceedings of the 14th International ${ }^{14} \mathrm{C}$ Conference. Radiocarbon 34(3):898905.

Donahue DJ, Jull A.JT, Linick TW, Toolin LJ. 1990a. Some archaeological applications of accelerator radiocarbon analysis. Nuclear Instrumentation Methods B45:561-564.

Donahue DJ, Linick TW, Jull AJT. 1990b. Isotope-ratio and background corrections for accelerator mass spectrometry radiocarbon measurements. Radiocarbon 32(2)135-142.

Eylon D. 2002. On the radiocarbon dating of iron. In: Kim G-H, Yi K-W, Kang H-T, editors. BUMA-V. Messages from the History of Metals to the Future Metal Age. Seoul: Korean Institute of Metals and Materials. p 161-168.

Fitzhugh WW. 1993. Exploration after Frobisher. In: Fitzhugh WW and Olin JS, editors. 1993. Archeology of the Frobisher voyages, Washington DC: Smithsonian Institution Press.

Fitzhugh WW, Olin JS, editors. 1993. Archeology of the Frobisher voyages. Washington DC: Smithsonian Institution Press.

Freestone IC, Tite MS. 1986. Refractories from the ancient and preindustrial world. In: Kingery W, editor. Ceramics and Civilisation III, Westerville, Ohio: American Ceramic Society. p 35-63.

Fulford MG, Allen JRL. 1992. Iron-making at the Chesters Roman Villa, Woolaston, Gloucestershire. Survey and excavation 1987-91. Britannia 23. Appendix by I. Figueiral on the fuels. p 188-91.

Gassman G, Yalçin Ü, Hauptmann A. 1995. Frühemittelalterliche Eisenproduktion in Kippenheim, Subaden: Ein "missing link" zwischen Rennverfahren und Röhleisentechnologie. Metalla 2(2)43-52.

Gordon RB. 1996. American iron 1607-1900. Baltimore: John Hopkins University Press.

Han Rubin. 1996. The development of Chinese ancient blast furnace. In: Igaki K, editor. The Proceedings of the Forum for the Fourth International Conference on the Beginnings of the Use of Metals and Alloys. Sendai: The Japan Institute of Metals. p 151-74.

Harbottle G, Cresswell RG, Stoenner RW. 1993. Carbon-
14 dating of iron blooms from Kodlunarn Island. In: Fitzhugh WW and Olin JS, editors. 1993. Archeology of the Frobisher Voyages. Washington DC: Smithsonian Institution Press. p 173-80.

Hart C. 1971. The industrial history of Dean. Newton Abbot, Devon: David and Charles.

Hartwell R. 1966. Markets, technology, and the structure of enterprise in the development of the eleventh century Chinese iron and steel industry. Journal of Economic History 26:29-58.

Hartwell R. 1967. A cycle of economic change in imperial China: coal and iron in northeast China, 7501350. Journal of Economic and Social History of the Orient 10:102-59.

Kenyon M. 1975. Tokens of possession: the northern voyages of Martin Frobisher. Ontario: Royal Ontario Museum.

Knau HL, Sönnecken M. 1994. Rennfeuer, Massenhütte, Hammerwerk. In: Mangin M, editor. La sidérgie ancienne de l'Est de la France dans son contexte européen. Paris: Les Belles Lettres. p 121-30.

Kusimba CM, Killick DJ, Cresswell RG. 1994. Indigenous and imported metals at Swahili sites on the coast of Kenya. Society, Culture and Technology in Africa, 11(Supplement):63-77.

Laeyendecker D. 1993. Wood and charcoal remains from Kodlunarn. In: Fitzhugh WW and Olin JS, editors. 1993. Archeology of the Frobisher Voyages. Washington DC: Smithsonian Institution Press. p 155-72.

Lang J, Craddock PT, Simpson St J. 1998. New evidence for early crucible steel. Journal of the Historical Metallurgy Society 32(1)7-14.

McFee W. 1928. The life of Sir Martin Frobisher. New York: Harper and Brothers.

Mack I, McDonnell G, Murphy S, Andrews P, Wardley K. 2000. Liquid steel in Anglo-Saxon England. Journal of the Historical Metallurgy Society 34(2):87-96.

Magnusson G. 1985. Lapphyttan-an example of medieval iron production. In: Hook E and Palsson R, editors. Medieval Iron in Society. Stockholm: Jernkontoret and Riksantikvarinëambetet. p 22-57.

Maréchal J-R. 1985. Methods of ore roasting and the furnaces used. In: Craddock PT and Hughes MJ, editors. Furnaces and Smelting Technology in Antiquity. London: British Museum Occasional Paper 48. p 29-42.

van der Merwe N. 1969. The Carbon-14 dating of iron. Chicago: University of Chicago Press.

Pounds NJG. 1971. The geography of iron and steel. London: Hutchinson.

Qui Shihua, Cai Liazhen. 1986. Woguo gudai yetie ranliao de tan-shisi jianding (Use of radiocarbon dating to determine the fuel used in ancient Chinese iron-smelting). In: Wang Zhongshu and An Zhimin, editors. Zhongguo kaoguxue yanjiu. Beijing: Wenwu Chubanshe. p 359-63. In Chinese.

Rostoker W, Bronson B. 1990. Pre-industrial iron. Philadelphia: Archeomaterials Monograph 1. 
Rostoker W, Dvorak J. 1990. Wrought iron: distinguishing between processes. Archeomaterials 4(2):153-66.

Sayre EV, Harbottle G, Stoenner RW, Washburn W, Olin JS, Fitzhugh WW. 1982. The Carbon-14 dating of an iron bloom associated with the voyages of Sir Martin Frobisher. In: Currie L, editor. Nuclear and Chemical Dating Techniques. ACS Symposium Series 176. Washington DC: American Chemical Society. p 44151.

Sherby OD, Wadsworth J. 2001. Ancient blacksmiths, the Iron Age, Damascus steels, and modern metallurgy. Journal of Materials Processing Technology 117(3):347-53.

Smith CS, Gnudi MT, translators and editors. 1942. The pirotechnia of Vannoccio Biringuccio. New York: Basic Books.

Starley D. 1999. Determining the technological origins of iron and steel. Journal of Archaeological Science 26(8):1127-33.

Stuiver M, Pearson GW. 1986. High-precision calibration of the radiocarbon time scale AD 1950-5000 BC.
Radiocarbon 28(2B):805-38.

Tylecote RF. 1992. A history of metallurgy, 2nd ed. London: The Metals Society.

Unglik H. 1993. Metallurgical study of an iron bloom and associated finds from Kodlunarn Island. In: Fitzhugh WW and Olin JS, editors. 1993. Archeology of the Frobisher Voyages. Washington DC: Smithsonian Institution Press. p 173-80.

Wagner D. 1993. Iron and steel in ancient China. Leiden: Brill.

Wagner D. 2001. Blast furnaces in Song-Yuan China. East Asian Science, Technology and Medicine 18:4174.

Wayman ML, Ehrenreich RM. 1993. Metallurgical study of small iron finds. In: Fitzhugh WW and Olin JS, editors. 1993. Archeology of the Frobisher Voyages. Washington DC: Smithsonian Institution Press. p 213-20.

Webster G. 1955. A note of the use of coal in Roman Britain. Antiquaries Journal 35(3/4):199-217. 